\title{
Isolation of Tibet orbivirus from Culicoides and associated infections in livestock in Yunnan, China
}

\author{
Jinglin Wang ${ }^{*}$, Huachun Li ${ }^{*}$ Y Yuwen He, Yang Zhou, Aiguo Xin, Defang Liao and Jinxin Meng
}

\begin{abstract}
Background: Culicoides-borne orbiviruses, such as bluetongue virus (BTV) and African horse sickness virus (AHSV), are important pathogens that cause animal epidemic diseases leading to significant loss of domestic animals. This study was conducted to identify Culicoides-borne arboviruses and to investigate the associated infections in local livestock in Yunnan, China.

Methods: Culicoides were collected overnight in Mangshi City using light traps during August 2013. A virus was isolated from the collected Culicoides and grown using baby hamster kidney (BHK-21), Vero, Madin-Darby bovine kidney (MDBK) and Aedes albopictus (C6/36) cells. Preliminary identification of the virus was performed by polyacrylamide gel (PAGE) analysis. A full-length CDNA copy of the genome was amplified and sequenced. Serological investigations were conducted in local cattle, buffalo and goat using plaque-reduction neutralization tests.

Results: We isolated a viral strain (DH13C120) that caused cytopathogenic effects in BHK-21, Vero, MDBK and C6/36 cells. Suckling mice inoculated intracerebrally with $\mathrm{DH} 13 \mathrm{C} 120$ showed signs of fatal neurovirulence. PAGE analysis indicated a genome consisting of 10 segments of double-stranded RNA that demonstrated a 3-3-3-1 pattern, similar to the migrating bands of Tibet orbivirus (TIBOV). Phylogenetic analysis of the viral RNA-dependent RNA polymerase (Pol), sub-core-shell (T2, and outer core (T13) proteins revealed that DH13C120 clustered with TIBOV, and the amino acid sequences of DH13C120 virus shared more than 98\% identity with TIBOV XZ0906. However, outer capsid protein VP2 and outer capsid protein VP5 shared only 43.1 and $79.3 \%$ identity, respectively, indicating that the DH13C120 virus belongs to TIBOV, and it may represent different serotypes with XZ0906. A serosurvey revealed the presence of neutralizing antibodies with 90\% plaque-reduction neutralization against TIBOV DH13C120 in local cattle (44\%), buffalo (20\%), and goat (4\%). Four-fold or higher levels of TIBOV-2-neutralizing antibody titers were detected between the convalescent and acute phases of infection in local livestock.
\end{abstract}

Conclusions: A new strain of TIBOV was isolated from Culicoides. This study provides the first evidence of TIBOV infection in livestock in Yunnan, China, and suggests that TIBOV could be a potential pathogen in livestock.

Keywords: Tibet orbivirus, Isolation, Culicoides, Whole genome analysis, Infection in animals

\footnotetext{
*Correspondence: Wangj1107@163.com; li_huachun@hotmail.com

Yunnan Animal Science and Veterinary Institute, Qinglongshan Jindian

PanLong District Kunming, Kunming, Yunnan province 650224, People's

Republic of China
} 


\section{Background}

The viral genus Orbivirus within the family Reoviridae has a genome consisting of 10 segments of doublestranded (ds) RNA. It contains 22 recognized virus species and 10 unclassified viruses [1]. BTV and AHSV negatively impact animal husbandry and veterinary health. In addition, Equine encephalosis virus (EEV), Epizootic hemorrhagic disease virus (EHDV), Palyam virus (PALV) and Peruvian horse sickness virus (PHSV) are important pathogens causing epidemic diseases in animals. In these orbiviruses, although PHSV is mosquito-borne, most of these viruses are carried by Culicoides [2, 3]. Therefore, Culicoides is considered a potent vector of important animal arbovirus diseases, which cause major economic losses in domestic animals [2, 4-6].

The TIBOV was first isolated from Anopheles maculatus mosquitoes collected in 2009 from Motuo County, Tibet, China [7]. Subsequently, TIBOV was isolated from Culex fatigan mosquitoes and Culicoides specimens collected from Guangdong and Yunnan, respectively [8]. Here, we report a new TIBOV named DH13C120, isolated from Culicoides. Sequence analysis of its entire genome and evidence of DH13C120 infection in local livestock were obtained from samples collected in the southwest border area of Yunnan Province in 2013.

\section{Methods}

\section{Collection of Culicoides specimens}

Specimens were collected during August 2013 from the suburb of Manbing Town in Mangshi City, Dehong Prefecture, Yunnan Province. Samples were collected overnight using light traps (12 V, 300 mA; Wuhan Lucky Star Environmental Protection Tech. Co., Ltd., Hubei, China). Captured Culicoides, killed by freezing at $-20{ }^{\circ} \mathrm{C}$ for $20 \mathrm{~min}$ and identified by using morphologic characteristics, were pooled into groups of approximately 100 insects and stored in liquid nitrogen until viral isolation.

\section{Isolation of viruses}

Culicoides pools, which included midges that were engorged or not engorged, were removed from liquid nitrogen and immediately homogenized and centrifuged as reported previously [9]. The supernatants were used to inoculate monolayers of baby hamster kidney (BHK-21) cells, Vero cells (from the China National Institute for Viral Disease Control and Prevention, Chinese Center for Disease Control and Prevention, Beijing, China), and Madin-Darby bovine kidney (MDBK) cells (From Yunnan biological pharmaceutical factory, Kunming, China) at $37^{\circ} \mathrm{C}$; Aedes albopictus (C6/36) cells (from the National Institute for Viral Disease Control and Prevention) were inoculated at $28{ }^{\circ} \mathrm{C}$. The cells were observed daily (days 1-7 post-inoculation) for cytopathic effects (CPEs).
Assay of neurovirulence in suckling mice

Aliquots of $30 \mu \mathrm{L}$ cell culture material (100 plaqueforming units, $\mathrm{PFU} / \mathrm{mL}$ ) were inoculated intracerebrally into 1-day-old suckling mice, and $30 \mu \mathrm{L}$ of Dulbecco's modified Eagle's medium (DMEM) was similarly applied in the control group, with eight suckling mice in each group. Symptoms (or the time of death) in the virustreated neonatal mice were recorded each day for 14 days post-inoculation.

\section{Polyacrylamide gel electrophoresis (PAGE)}

To reveal the number of dsRNA segment and the genome pattern, viral RNA was extracted using RNAiso Plus (TaKaRa, Dalian, China) according to the manufacturer's protocols, and then separated on RNA-PAGE as described previously [9-11].

\section{Full genome sequencing}

The virus genome was amplified by full-length amplification of cDNA (FLAC), as described previously $[9,12,13]$. Briefly, viruses were propagated in BHK-21 cells, and total RNA was extracted using RNAiso Plus (TaKaRa) according to the manufacturer's protocols. Single stranded (ss) RNAs were removed by precipitation with $2 \mathrm{M} \mathrm{LiCl}$ (Sigma-Aldrich, St Louis, MO, USA), and dsRNAs were precipitated by the addition of 2.5 volumes of isopropanol and 1 volume of $7.5 \mathrm{M}$ ammonium acetate. The dsRNAs were subjected to $1 \%$ agarose gel electrophoresis (AGE) $(7 \mathrm{~V} / \mathrm{cm}$, for $1 \mathrm{~h})$ in TAE buffer $(40 \mathrm{mMTris}$-acetate, $1 \mathrm{mM}$ EDTA, $\mathrm{pH}$ 8.0) and purified from the agarose gel using MinElute gel extraction kits (Qiagen, Hilden, Germany).

An anchor primer, PC3-T7 loop (synthesized by Sangon, Shanghai, China), similar to that described by Maan et al. [13], was ligated to the viral dsRNA. Ligation reactions were carried out in a total volume of $30 \mu \mathrm{L}$, as described previously $[9,12]$. The ligated dsRNA was purified using MicroElute RNA Cleanup kits (Omega Bio-Tek Inc., Norcross, GA, USA), denatured with dimethyl sulfoxide (DMSO) for a final concentration of $15 \%(\mathrm{v} / \mathrm{v})$, heated in boiling water for $2 \mathrm{~min}$, and snapfrozen in an ice-water slurry. The full-length complementary DNAs (cDNAs) of 10 viral dsRNA segments were synthesized in a total volume of $50 \mu \mathrm{L}$ using a PrimeScript II high-fidelity reverse transcription polymerase chain reaction (RT-PCR) kit (TaKaRa) according to the manufacturer's recommendations. Amplification of the cDNA was carried out with primer PC2 in a total volume of $50 \mu \mathrm{L}$, as described previously $[9,12]$. The PCR products were viewed after separation on $1 \%$ agarose gels in $1 \times$ TAE buffer containing a nucleic acid dye, and purified using TaKaRa DNA fragment purification kits (ver. 2.0; TaKaRa). The gel-purified fragments were cloned into the pMD19-T vector (TaKaRa), and 
introduced into chemically competent Escherichia coli DH $\alpha 5$ cells (TaKaRa). Single colonies were cultured and sequenced by the Shenzhen Huada Genome Institute, Shanghai, China. We performed 2 sequencings from the same RNA extraction and these sequences (that include the differences) were cover 2.5 times.

\section{Sequence analysis and phylogenetic comparisons}

Initial sequence assembly and analyses were conducted using the DNAStar software package (ver. 4.0; DNASTAR Inc., Madison, WI, USA). Homology and alignment analysis was performed using Clustal $\mathrm{X}$ (ver. 2.1) [9] (http://www.directoryofshareware.com/preview/clustalx/ ) and MegAlign (DNASTAR Inc.). Phylogenetic and evolutionary analyses were conducted using MEGA 5.1 (http://www.megasoftware.net/) based on the neighborjoining technique and 1,000 bootstrap replications [9].

\section{Serological investigations of antibodies against TIBOV isolate $\mathrm{DH} 13 \mathrm{C} 120$ \\ Sample collection}

Buffalo serum samples were collected in Mangshi City, Dehong Prefecture, Yunnan Province in 2009. The separated serum samples were stored at $-20{ }^{\circ} \mathrm{C}$ until tested. In 2013, three collection sites were chosen, in Mangshi City, Jiangcheng County of Pu'er City, and Shizong County of Qiujing City. Sentinel animals were picked from and existing population if they were first shown to serologically naïve on the May. Ten cattle and five goats were chosen as sentinel animals for each collection site, and serum samples were collected monthly and stored at $-20{ }^{\circ} \mathrm{C}$ until tested.

\section{Plaque-reduction neutralization tests}

Serum samples were tested for neutralizing antibodies against TIBOV isolate $\mathrm{DH} 13 \mathrm{C} 120$ by $90 \%$ plaquereduction neutralization tests (PRNT 90) using standard methods. Samples were tested with serial two-fold dilutions from 1:10 to 1:1,280. Diluted samples were mixed with equal volumes of culture medium $1 \times \mathrm{MEM}(\mathrm{pH}=7.4)$ containing DH13C120 (100 PFU) and incubated at $37^{\circ} \mathrm{C}$ in a $5 \% \mathrm{CO}_{2}$ for $1 \mathrm{~h}$. Six-well plates of confluent BHK-21 cells were inoculated with the serum-virus mixtures and incubated at $37{ }^{\circ} \mathrm{C}$ in a $5 \% \mathrm{CO}_{2}$ incubator for $1 \mathrm{~h}$. Plates were overlaid with $3 \mathrm{~mL}$ of the same medium containing $0.8 \%$ agarose, and again with $3 \mathrm{~mL}$ of a second overlay medium containing neutral red vital stain (Sigma-Aldrich). The neutralizing antibody titer was identified as the highest serum dilution that reduced the number of virus plaques in the test by $\geq 90 \%$. The samples were considered to be positive when titers were $\geq 20$. A ratio of TIBOV PRNT 90 titer between two samples of a same animal $\geq 4$ was considered to confirm the presence of a TIBOV infection [14].

\section{Results}

Isolation of viruses

Culicoides were processed to isolate viruses in BHK-21, Vero and C6/36 cells. A CPE was observed with one pool (DH13C120) collected from Dehong. Isolate DH13C120 caused CPEs in BHK-21, Vero, MDBK and C6/36 cells at $48,48,144$, and $120 \mathrm{~h}$ post-infection, respectively. The characteristic CPE in BHK-21, Vero and C6/36 cells infected with DH13C120 was rounding and desquamation, whereas that in MDBK cells showed vacuolization and desquamation.

\section{Assay of neurovirulence in suckling mice}

Suckling mice inoculated intracerebrally with DH13C120 showed signs of tremor and stiff necks at $48 \mathrm{~h}$, and died within $72 \mathrm{~h}$.

\section{Gel separation}

Separation by PAGE revealed that DH13C120 is a 10 -segment dsRNA virus, with a segment pattern of 3-3-3-1 (Fig. 1).

Genome organization and characteristics of $\mathrm{DH} 13 \mathrm{C} 120$ virus A full length cDNA copy of the DH13C120 virus genome was obtained by FLAC and sequencing, with the length of segments 1-10 ranging between 3,740 nucleotides (nt) (Seg-1) to $788 \mathrm{nt}$ (Seg-10) (Table 1). The sequences of the 10 segments were deposited in the NCBI GenBank with the accession numbers KU754026-KU754035, as indicated in Table 1. Compared with the TIBOV XZ0906 strain, the $\mathrm{DH} 13 \mathrm{C} 120$ virus has $12 \mathrm{nt}$ insertions in the open reading frame and $1 \mathrm{nt}$ insertion in the $3^{\prime}$ untranslated region (UTR) in Seg-2, and $5 \mathrm{nt}$ insertions in the $5^{\prime}$ UTR and $1 \mathrm{nt}$ insertion in the 3' UTR in Seg-6. Conserved nt sequences of $6 \mathrm{nt}$ were observed at the ends of the 5' and 3' UTRs $\left(5^{\prime}-\right.$ GTAAAA $^{\mathrm{A}} / \mathrm{T}$ and $\left.\mathrm{C} /{ }_{\mathrm{A}} \mathrm{ACTTAC}-3^{\prime}\right)$, and $4 \mathrm{nt}$ in the terminal sequences were reverse complementary. The $5^{\prime}$ and 3' UTRs of DH13C120 comprised 3.80\% of the total genome; the $\mathrm{G}+\mathrm{C}$ content of $\mathrm{DH} 13 \mathrm{C} 120$ was $42.59 \%$, similar to Culicoides-borne Orbivirus species; and an ArgGly-Asp (RGD) motif [15-17] was observed at position 168-170 in the viral outer core protein T13 (VP7) of DH13C120.

\section{Phylogenetics \\ Phylogenetic analysis of DH13C120 virus compared with TIBOV (XZ0906, Fengkai and YN12246)}

The sub-core-shell (T2) (VP3) protein of DH13C120 is encoded by segment 3. Phylogenetic analvysis showed that DH13C120 has a close relationship with TIBOV XZ0906, YN12246 (only partial nt sequence of the T2 protein) and Fengkai virus. Amino acid (aa) sequence analysis of the T2 protein revealed $96.3-99.9 \%$ sequence similarity between $\mathrm{DH} 13 \mathrm{C} 120$ and the TIBOV species 


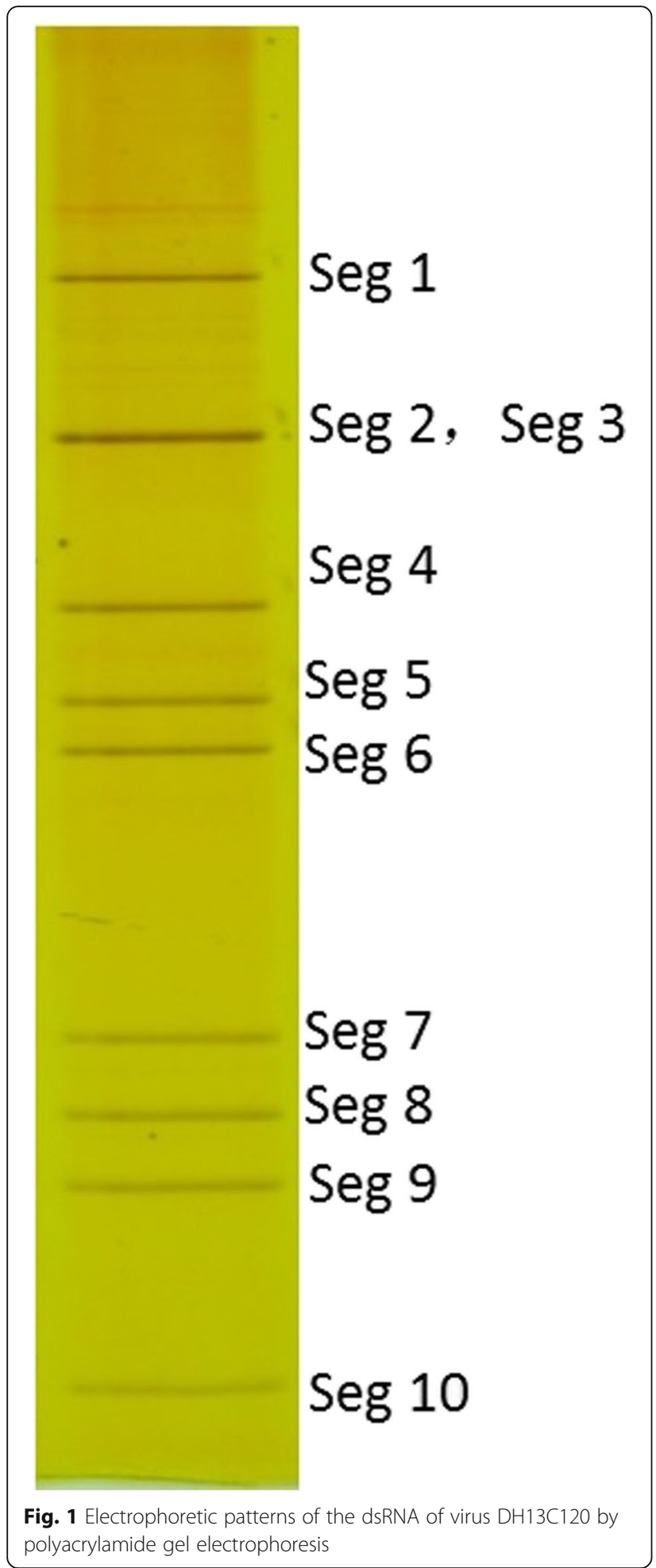

(XZ0906, YN1226 and Fengkai virus), which was above the threshold of $91 \%$ used for species determination by Attoui et al. [18]. This similarity confirmed that DH13C120 is a strain of TIBOV.
Sequence analysis of the outer capsid VP2 (encoded by segment 2) protein of TIBOV isolated from China (DH13C120, XZ0906 and the Fengkai virus) revealed that the DH13C120 virus isolated from Culicoides in Yunnan and the Fengkai virus isolated from mosquitoes in Guangdong (partial sequence) had sequence similarities of $96.8 \% / 97.1 \%$ nt/aa, whereas XZ0906 isolated from mosquitoes in Tibet displayed similarities of 53.9\%/43.1\% nt/aa (Table 2).

\section{Phylogenetic analysis of DH13C120 compared with other Orbivirus species}

To clarify the taxonomic position of DH13C120 with other Orbivirus species, we conducted phylogenetic analyses of the predicted aa sequences of RNA-dependent RNA polymerase (Pol) (VP1), T2 (VP3), and T13 (VP7) (Fig. 2). The phylogenetic trees revealed that the phylogeny was often correlated with a particular arthropod vector and could be classified into two groups: Orbivirus species transmitted by Culicoides (including BTV, AHSV, EHDV, Wallal virus, Eubenangee virus, Warrego virus, and PALV), and those transmitted by ticks (such as Great island virus, GIV) or mosquitoes (such as Corriparta virus, Wongorr virus, PHSV, and Yunnan Orbivirus (YUOV). Phylogenetic analysis showed that DH13C120 has a close relationship and similar coding pattern to other Culicoides-borne Orbivirus species. The Pol, T2, and T13 proteins of DH13C120 share 58-71.8\%, 57.6-77.8\%, and $40.6-68.2 \%$ aa sequence identity with the Culicoidesborne Orbivirus species, respectively, and 47\%, 38\%, and $23.6 \%$ aa identity with mosquito-borne YUOV, respectively.

\section{Prevalence of $\mathrm{DH} 13 \mathrm{C} 120$ virus antibodies in local livestock}

A total of 135 serum samples were collected from cattle, buffaloes and goats in Mangshi City, Jiangcheng and Shizong County of Yunnan. Neutralizing antibodies against DH13C120 virus were detected by PRNT 90 assays. Most of the positive samples were collected in Jiangcheng County, with the highest seroprevalence (90\%) in cows. Additionally, positive sera were collected in Mangshi City (27\%) and Shizong County (10\%), but positivity rates in both areas were much lower than those in Jiangcheng County (Table 3).

To understand the dynamics of infection by this orbivirus, five goats and ten cows were chosen as target animals at each of the three monitoring sites. Seroconversion of neutralization antibodies were detected in the target cattle (Table 4), with $9 / 10$ in Jiangcheng County, 3/10 in Mangshi City, and only 1/10 in Shizong County. However, no seroconversion was detected in the target sheep. The period of seroconversion was from June to September (Table 4). This result illustrated that cattle 
Table 1 Lengths of dsRNA segments 1-10, encoded putative proteins, 5'and 3'NCRs of DH13C120 virus genome

\begin{tabular}{|c|c|c|c|c|c|c|c|c|}
\hline Segment & $\begin{array}{l}\text { Length } \\
\text { (bp) }\end{array}$ & GC\% & $\begin{array}{l}\text { Protein } \\
\text { (aa) }\end{array}$ & $\begin{array}{l}5^{\prime} \mathrm{NCR} \\
(\mathrm{bp})\end{array}$ & $\begin{array}{l}\text { Terminal sequence } \\
\left(5^{\prime}-3^{\prime}\right)\end{array}$ & $\begin{array}{l}3^{\prime} \mathrm{NCR} \\
(\mathrm{bp})\end{array}$ & Putative function & $\begin{array}{l}\text { GenBank } \\
\text { Accession no. }\end{array}$ \\
\hline S1 & 3950 & 41.32 & 1304 & 11 & $\begin{array}{l}\text { GUAAAAUCA- } \\
\text { AUACACUUAC }\end{array}$ & 24 & VP1: RNA-dependent RNA polymerase & KU754026 \\
\hline S2 & 2901 & 40.09 & 950 & 13 & $\begin{array}{l}\text { GUAAAAAUC- } \\
\text { UUAAACUUAC }\end{array}$ & 35 & $\begin{array}{l}\text { VP2: outer capsid protein; controls virus serotype; } \\
\text { most variable protein; contains neutralizing epitopes }\end{array}$ & KU754027 \\
\hline S3 & 2769 & 44.42 & 899 & 17 & $\begin{array}{l}\text { GUAAAAUUU- } \\
\text { AUACACUUAC }\end{array}$ & 52 & VP3(T2): forms sub-core capsid layer & KU754028 \\
\hline S4 & 1978 & 42.82 & 643 & 8 & $\begin{array}{l}\text { GUAAAAACA- } \\
\text { UUACACUUAC }\end{array}$ & 38 & $\begin{array}{l}\text { VP4: Cap; protein within the sub-core; shows } \\
\text { capping activities and methyltransferase type } \\
1 \text { and type } 2 \text { activities }\end{array}$ & KU754029 \\
\hline S5 & 1775 & 43.83 & 554 & 31 & $\begin{array}{l}\text { GUAAAAAAG- } \\
\text { UUACACUUAC }\end{array}$ & 79 & $\begin{array}{l}\text { NS1: TuP; forms tubules of unknown function } \\
\text { within the cytoplasm of infected cells }\end{array}$ & KU754030 \\
\hline S6 & 1642 & 43.42 & 526 & 31 & $\begin{array}{l}\text { GUAAAAAGA- } \\
\text { UUUCACUUAC }\end{array}$ & 30 & VP5: outer capsid protein & KU754031 \\
\hline S7 & 1165 & 44.72 & 349 & 17 & $\begin{array}{l}\text { GUAAAAAUU- } \\
\text { UUACACUUAC }\end{array}$ & 98 & $\begin{array}{l}\text { VP7(T13): immunodominant major serogroup } \\
\text { specific antigen }\end{array}$ & KU754032 \\
\hline S8 & 1142 & 41.94 & 359 & 20 & $\begin{array}{l}\text { GUAAAAAAU- } \\
\text { UUAAACUUAC }\end{array}$ & 42 & NS2: single-stranded RNA-binding protein & KU754033 \\
\hline 59 & 1100 & 44.73 & 346 & 14 & $\begin{array}{l}\text { GUAAAAAAU- } \\
\text { UAAAACUUAC }\end{array}$ & 45 & $\begin{array}{l}\text { VP6: helicase for unwinding and binding to } \\
\text { ssRNA and dsRNA; NTPase }\end{array}$ & KU754034 \\
\hline \multirow[t]{3}{*}{ S10 } & 832 & 41.47 & 234 & 21 & $\begin{array}{l}\text { GUAAAAAAG- } \\
\text { CCCAACUUAC }\end{array}$ & 106 & NS3: involved in cell exit; glycoprotein & KU754035 \\
\hline & & \multirow[t]{2}{*}{42.59} & \multirow{2}{*}{\multicolumn{2}{|c|}{ Consensus }} & GUAAAA ${ }^{A} / u$ & & & \\
\hline & & & & & C/AACUUAC & & & \\
\hline
\end{tabular}

are susceptible to the DH13C120 virus and may play an important role in viral diffusion and dissemination.

\section{Discussion}

The parameters recognized by the International Committee on Taxonomy of Viruses for the polythetic definition of individual Orbivirus species include: the reassortment of genome segments; genome segment migration patterns shown by $1 \%$ agarose gel electrophoresis; conserved terminal nt sequences; serological cross-reactions; comparison of homologous genome segments or proteins by sequence analysis or cross-hybridization; host and vector ranges; and the nature of clinical signs induced by infection $[19,20]$. In this study, some features of DH13C120 resembled the

Table 2 Comparison of each segment between virus DH13C120 and other Orbiviruses in nucleotide and amino acid identities

\begin{tabular}{|c|c|c|c|c|c|c|c|c|c|c|c|c|c|c|c|c|}
\hline \multirow[t]{2}{*}{ Segment } & \multicolumn{2}{|c|}{ TIBOV (XZ0906) } & \multicolumn{2}{|c|}{ TIBOV (YN1226) } & \multicolumn{2}{|c|}{ TIBOV (Fengkai) } & \multicolumn{2}{|c|}{ Pata virus } & \multicolumn{2}{|l|}{ BTV-1 } & \multicolumn{2}{|c|}{ EHDV-2 } & \multicolumn{2}{|c|}{ CHUNV } & \multicolumn{2}{|l|}{ YOUV } \\
\hline & $\mathrm{nt}(\%)$ & $\mathrm{aa}(\%)$ & $\mathrm{nt}(\%)$ & $\mathrm{aa}(\%)$ & $\mathrm{nt}(\%)$ & $\mathrm{aa}(\%)$ & $\mathrm{nt}(\%)$ & $\mathrm{aa}(\%)$ & $\mathrm{nt}(\%)$ & $\mathrm{aa}(\%)$ & $\mathrm{nt}(\%)$ & $\mathrm{aa}(\%)$ & $\mathrm{nt}(\%)$ & $\mathrm{aa}(\%)$ & $\mathrm{nt}(\%)$ & $\mathrm{aa}(\%)$ \\
\hline S1(VP1) & 92.0 & 98.6 & $90.9^{a}$ & $98.5^{a}$ & 91 & 98.5 & 67.8 & 71.8 & 66.5 & 71.0 & 66.9 & 70.6 & 58.8 & 58 & 52.4 & 47 \\
\hline S2(VP2) & 53.9 & 43.1 & - & - & $96.8^{b}$ & 97.1 & 46.2 & 26.5 & 44.0 & 25.2 & 45.7 & 23.3 & 44.1 & 21.9 & 42.4 & 21.8 \\
\hline S3(VP3) & 96.5 & 99.9 & $79.5^{\mathrm{a}}$ & $96.3^{a}$ & 96 & 99.8 & 69.4 & 77.8 & 68.4 & 75.2 & 69.4 & 76.0 & 60.7 & 57.6 & 47.4 & 38.0 \\
\hline S4(VP4) & 96.6 & 98.0 & - & - & 96.1 & 98.3 & 61.0 & 63.0 & 62.5 & 64.6 & 62.0 & 64.3 & 53.6 & 41.0 & 48.8 & 48.2 \\
\hline S5(NS1) & 96.8 & 99.8 & - & - & 93.4 & 99.7 & 52.7 & 45.2 & 49.9 & 39.1 & 49.9 & 40.7 & 41.6 & 27.6 & 36.4 & 25.9 \\
\hline S6(VP5) & 70.4 & 79.3 & - & - & 94.8 & 98.9 & 61.1 & 62.9 & 59.4 & 59.4 & 60.0 & 61.3 & 51.2 & 45.5 & 45.1 & 30.9 \\
\hline S7(VP7) & 98.9 & 99.7 & - & - & 93.5 & 99.1 & 66.0 & 68.2 & 61.6 & 60.2 & 61.9 & 61.3 & 51.6 & 40.6 & 36.4 & 23.6 \\
\hline S8(NS2) & 88.4 & 97.2 & - & - & 96.8 & 98.3 & 60.9 & 41.5 & 59.5 & 31.3 & 59.8 & 35.6 & 53.9 & 32.0 & 46.7 & 26.0 \\
\hline S9(VP6) & 96.4 & 94.2 & - & - & 96.4 & 94.2 & 61.6 & 46.3 & 44.5 & 33.9 & 59.5 & 38.9 & 41.2 & 30.4 & 38.1 & 31.2 \\
\hline S10(NS3) & 98.4 & 99.6 & - & - & 85.5 & 94.5 & 60.7 & 55.4 & 57.6 & 54.8 & 59.2 & 53.5 & 36.7 & 35.0 & 38.0 & 25.8 \\
\hline
\end{tabular}

Genbank accession numbers for virus sequences used for comparison: 1) TIBOV(XZ0906): KF746187- KF746196; 2) TIBOV (YN1226): KP099640(VP1), KP099641(VP3); 3) TIBOV (Fengkai): NC_027803- NC_027815; 4) Pata virus: JQ070386- JQ070395; 5) BTV-1: KF664123- KF664132; 6) EHDV-2: KM509050- KM509059; 7) CHUNV: NC_005986-NC_005995; 8) YOUV: NC_007656- NC_007665

apart sequence;-:No corresponding sequence

${ }^{\mathrm{b}}$ Fengkaivirus Seg-2: analyse only using $2779 \mathrm{nt}$ of 5 '-end sequence 

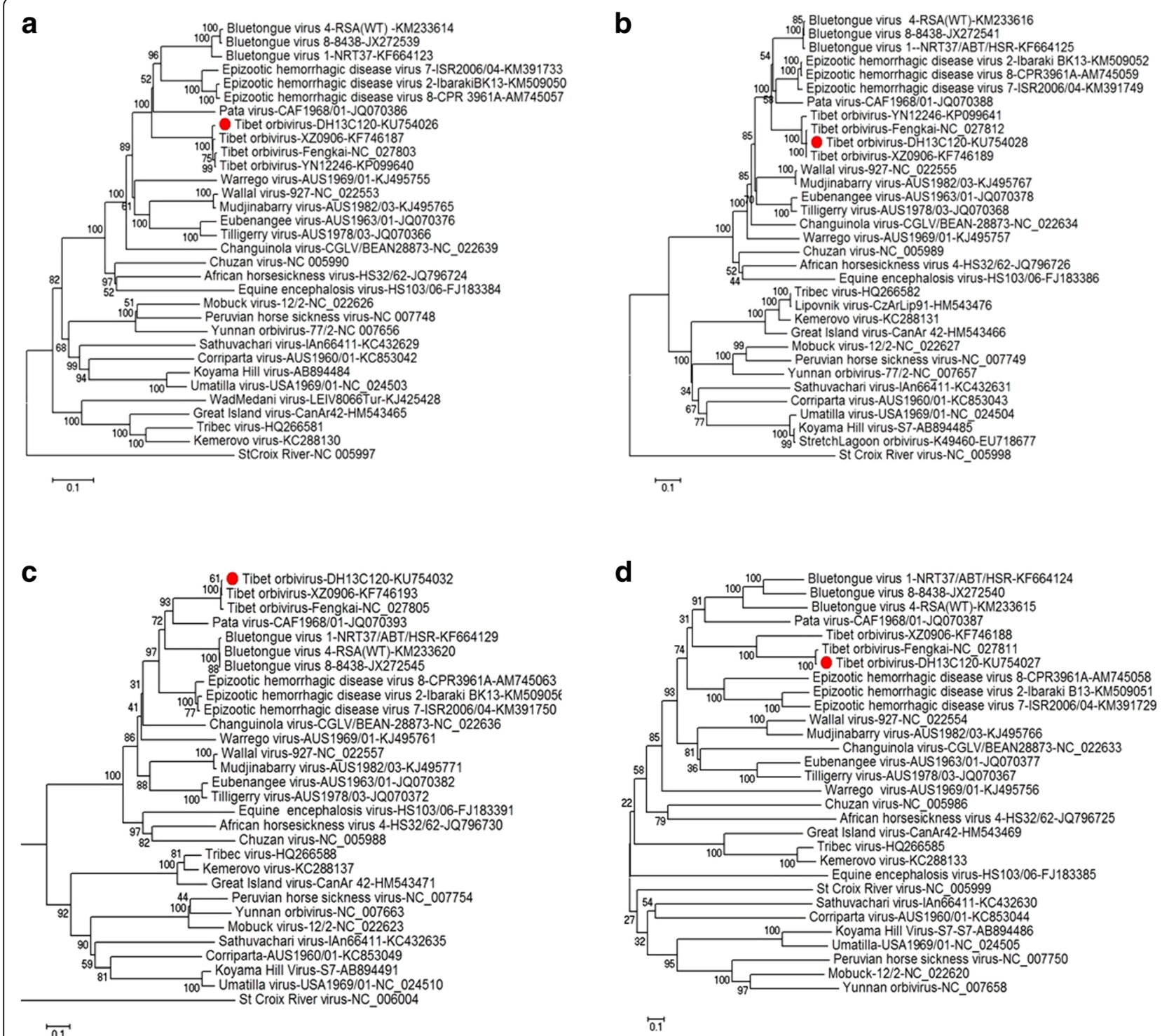

$\overrightarrow{0.1}$

Fig. 2 Phylogenetic analysis of the complete amino acid sequences of the corresponding viral proteins (VPs, see Table 1) of DH13C120 using representative members of the genus Orbivirus. a RNA-dependent RNA polymerase (Vol) (VP1); b T2 layer of core/subcore (VP3:Bluetongue virus (BTV), Epizootic hemorrhagic disease virus (EHDV), Tibet orbivirus (TIBOV), Pata virus, Wallal virus, Mudjinabary virus, Eubenangee virus, Warrego virus, Tilligerry virus, Changuinola virus, African horse sickness virus, Chuzan virus; VP2:Mobuck virus, Peruvian horse sickness virus, Yunnan orbivirus, Sathuvachai virus, Coriparta virus, Koyama Hill virus, Umatilla virus, Wadmedani virus, Great island virus, Tribec virus, Kemerovo virus, Stcroix River virus); c T13 sub-core capsid layer (VP7); d outer capsid protein (VP2)

Table 3 Results of PNPT90 antibody against TIBOV from cattle, buffalo and goat serum samples in the Yunnan

\begin{tabular}{lllll}
\hline Species & SZ & DH & JC & Total \\
\hline Cattle & $1 / 10(10 \%)$ & $12 / 30(40 \%)$ & $9 / 10(90 \%)$ & $22 / 50(44 \%)$ \\
Buffalo & NA & $12 / 60(20 \%)$ & NA & $12 / 60(20 \%)$ \\
Goat & $0 / 5(0)$ & $1 / 15(6.67 \%)$ & $0 / 5(0)$ & $1 / 25(4 \%)$ \\
Total & $1 / 15(6.67 \%)$ & $25 / 105(23.81 \%)$ & $9 / 15(60 \%)$ & $35 / 135(25.93 \%)$ \\
\hline
\end{tabular}

XZ0906 strain of TIBOV isolated from mosquitoes in Tibet [7] in terms of CPE, genome segment migration patterns, and conserved terminal nt sequences of the $5^{\prime}$ and $3^{\prime}$ UTRs, suggesting that DH13C120 belongs to the TIBOV species of the Orbivirus genus.

Conserved sequence from T2, Pol or T13 protein genes had previously been used for phylogenetic comparisons and taxonomic classification of Orbivirus [19, 21-23]. Among Orbivirus species, these proteins shared $>83 \%,>73 \%$ and $>73 \%$ aa identity, respectively $[18,19,22,24]$. DH13C120 and TIBOV shared 
Table 4 Dynamic level of antibody against TIBOV DH13C120 strain in the target animal of 3 monitoring spots in Yunnan

\begin{tabular}{|c|c|c|c|c|c|c|c|c|c|c|}
\hline NO. & Animal & Place & May & June & July & August & September & October & November & December \\
\hline $\mathrm{DH} 03$ & Cattle & Mangshi & $<1: 10$ & $<1: 10$ & $<1: 10$ & $<1: 10$ & $1: 20$ & $1: 80$ & $1: 80$ & $1: 160$ \\
\hline $\mathrm{DH} 05$ & Cattle & Mangshi & $<1: 10$ & $<1: 10$ & $<1: 10$ & $<1: 10$ & $1: 20$ & $1: 80$ & $1: 160$ & $1: 320$ \\
\hline $\mathrm{DH} 07$ & Cattle & Mangshi & $<1: 10$ & $<1: 10$ & $<1: 10$ & $1: 10$ & $1: 20$ & $1: 80$ & 1:160 & $1: 640$ \\
\hline $\mathrm{JCO6}$ & Cattle & Jiangcheng & $<1: 10$ & $1: 10$ & $1: 40$ & $1: 320$ & $1: 320$ & $1: 640$ & $1: 1280$ & \\
\hline $\mathrm{JCO}$ & Cattle & Jiangcheng & $<1: 10$ & $<1: 10$ & $1: 10$ & $1: 40$ & $1: 80$ & $1: 80$ & $1: 80$ & \\
\hline JCO9 & Cattle & Jiangcheng & $<1: 10$ & $<1: 10$ & $<1: 10$ & $1: 20$ & $1: 40$ & $1: 40$ & $1: 40$ & \\
\hline $\mathrm{JC} 10$ & Cattle & Jiangcheng & $<1: 10$ & $<1: 10$ & $<1: 10$ & $<1: 10$ & $1: 40$ & $1: 80$ & $1: 320$ & \\
\hline $\mathrm{JC} 11$ & Cattle & Jiangcheng & $<1: 10$ & $<1: 10$ & $<1: 10$ & $1: 20$ & $1: 320$ & $1: 640$ & $1: 640$ & \\
\hline $\mathrm{JC} 12$ & Cattle & Jiangcheng & $<1: 10$ & $1: 10$ & $1: 160$ & $1: 160$ & $1: 640$ & $1: 640$ & $1: 1280$ & \\
\hline $\mathrm{JC} 13$ & Cattle & Jiangcheng & $<1: 10$ & $1: 10$ & $1: 40$ & $1: 40$ & $1: 80$ & $1: 1280$ & 1:640 & \\
\hline JC14 & Cattle & Jiangcheng & $<1: 10$ & $<1: 10$ & $<1: 10$ & $1: 10$ & $1: 80$ & $1: 80$ & $1: 80$ & \\
\hline $\mathrm{JC} 15$ & Cattle & Jiangcheng & $<1: 10$ & $<1: 10$ & $<1: 10$ & $1: 20$ & $1: 40$ & $1: 640$ & $1: 640$ & \\
\hline SZO3 & Cattle & Shizong & $<1: 10$ & $<1: 10$ & $<1: 10$ & $<1: 10$ & $1: 10$ & $1: 20$ & $1: 20$ & \\
\hline
\end{tabular}

97\% aa identity in the above-mentioned conserved proteins. In contrast, they showed lower levels of aa identity $(<77.8 \%)$ with T2, Pol and T13 protein in other Orbivirus species. These data confirmed that DH13C120 is closely related to TIBOV. However, DH13C120 and TIBOV shared only $43.1 \%$ aa identity in the outer capsid protein VP2, and $79.3 \%$ aa identity in the outer capsid protein VP5. The outer capsid protein VP2 of the Orbivirus genus is an outer capsid protein; outer capsid protein VP2 is highly variable and determines viral serotype $[21,25,26]$. A pairwise alignment of outer capsid protein VP2s from different serotypes of BTV, EHDV and AHSV indicated variations in the ranges of $28.3-64 \%, 31.1-76.7 \%$, and $46-52 \%$ aa, respectively [26-28]. Based on these data, although the DH13C120 virus and TIBOV belong to the same species, they may represent different serotypes.

In terms of vectors, the genus Orbivirus contains Culicoides-borne, mosquito-borne and tick-borne viruses [21]. Although TIBOV has been isolated from both Culex and Culicoides, phylogenetic analysis of T2, polymerase proteins and $\mathrm{T} 13$ proteins reveals that TIBOV is more closely related with the Culicoidesborne Orbivirus. Furthermore, Pol, T2, T13 proteins of DH13C120 share higher aa sequence identities with the Culicoides-borne Orbivirus than the mosquito- or tickborne Orbivirus species, suggesting that Culicoides may be biological vectors of DH13C120 virus.

Previous studies have shown that the noncoding region (NCR) comprises 5.03-5.695\% of Orbivirus genomes in the mosquito-borne group, $4.47-4.9 \%$ in the tick-borne group, and 3.5-4.1\% in the Culicoides-borne group [22]. Analysis of the DH13C120 genome showed that the NCR comprises $3.80 \%$ of the genome, within the range of the Culicoides-borne group. In addition, the
$\mathrm{G}+\mathrm{C}$ content was $42.59 \%$ in $\mathrm{DH} 13 \mathrm{C} 120$, which was within the range for Culicoides-borne Orbivirus species (from $39.89 \%$ in Chuzan virus to $45.89 \%$ in EEV) [19, 22], but more than that in the mosquito-borne species (from $36.72 \%$ in PHSV to $41.55 \%$ in YUOV) and less than that in the tick-borne species (from 57.29\% in GIV to $51.93 \%$ in St Croix River virus). These data suggested that $\mathrm{DH} 13 \mathrm{C} 120$ virus is more or most related to viruses vectored by Culicoides spp.

For Culicoides-borne Orbivirus species, such as BTV, EHDV, and AHSV, a highly conserved RGD motif was present at position 168-170 of VP7 (T13, core-surface protein), which could play a role in the attachment of core particles to Culicoides cells [15-17]. An RGD motif was observed at position 168-170 in T13(VP7) of TIBOV, DH13C120, XZ0906, and Fengkai virus, reflecting its closer overall similarity to BTV and EHDV, and potentially implicating Culicoides spp. as biological vectors.

In 1995, 17 strains of Orbivirus were first isolated from ticks, birds, rats, and livestock in the Yadong and Cuona areas of Tibet, with typical CPE in BHK-21 cells and lethal illness in suckling mice. Antibodies against the Orbivirus isolates were detected in local residents with a seroprevalence of $26 \%$, suggesting that the new Orbivirus isolates could potentially be a novel animal pathogen in China [29, 30]. Recently, a new species, TIBOV, which could also generate CPE in BHK-21 cells, was isolated from mosquitoes and Culicoides in Yunnan, Guangdong Province and Tibet $[7,8]$. In the present study, a new serotype of TIBOV was isolated from Culicoides in Yunnan, and high levels of neutralization antibodies were detected in cattle serum from three areas in Yunnan Province. Moreover, neutralization antibodies against DH13C120 were detected in target animals at all three monitoring sites, with the highest positivity rate being 
$92 \%$. In addition, neutralization antibody titers that increased more than four-fold were detected in target cattle, and sheep inoculated with DH13C120 experienced fever (data not shown), suggesting that DH13C120 can infect livestock and is a potential pathogen leading to livestock disease.

In this study, DH13C120 was isolated from Culicoides collected in cattle corrals, and neutralization antibodies were detected in animals from the same areas. Seroconversion in animals occurred from June to September, which matched the seasonal peak of Culicoides numbers. These results suggest that Culicoides is the main vector of this new serotype of TIBOV, and cattle form the natural host reservoir. The cattle in these localities have high economic value, and most cattle are bred together in herds numbering over 100 . The density of Culicoides was high in these cattle corrals, facilitating circulation of the new serotype. To understand the impact of this new TIBOV serotype, further studies are required to characterize its dissemination and pathogenicity.

\section{Conclusions}

This investigation represents the isolation of TIBOV from Culicoides, and provides the first evidence of TIBOV DH13C120 strain infections in local livestock bred in the southwest border area of Yunnan, China. The results suggest that TIBOV isolated from Culicoides in yunnan, might be a pathogen causing livestock disease.

\begin{abstract}
Abbreviations
AHSV: African horse sickness virus; BHK-21: Baby hamster kidney; BTV: bluetonque virus; C6/36: Aedes albopictus; CDNAs: Complementary DNAs; CPEs: Cytopathic effects; DMEM: Dulbecco's modified Eagle's medium; DMSO: Dimethyl sulfoxide; EEV: Equine encephalosis virus; EHDV: Epizootic hemorrhagic disease virus; FLAC: Fulllength amplification of CDNA; GIV: Great island virus; MDBK: Madin-Darby bovine kidney; PAGE: Polyacrylamide gel; PALV: Palyam virus; PFU: Plaque-forming units; PHSV: Peruvian horse sickness virus; PRNT 90: 90\% plaque-reduction neutralization tests; RT-PCR: Reverse transcription polymerase chain reaction; TIBOV: Tibet orbivirus; UTR: Untranslated region; YUOV: Yunnan Orbivirus
\end{abstract}

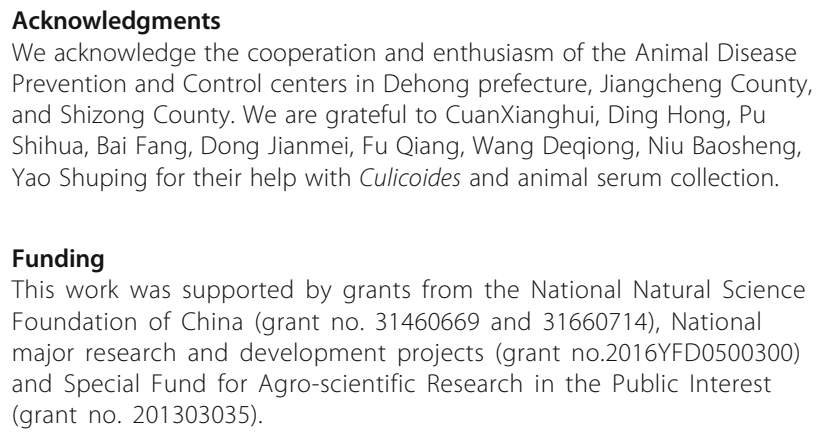

We acknowledge the cooperation and enthusiasm of the Animal Disease Prevention and Control centers in Dehong prefecture, Jiangcheng County, and Shizong County. We are grateful to CuanXianghui, Ding Hong, Pu Shihua, Bai Fang, Dong Jianmei, Fu Qiang, Wang Deqiong, Niu Baosheng, Yao Shuping for their help with Culicoides and animal serum collection.

\section{Funding}

This work was supported by grants from the National Natural Science Foundation of China (grant no. 31460669 and 31660714), National major research and development projects (grant no.2016YFD0500300) and Special Fund for Agro-scientific Research in the Public Interest (grant no. 201303035).

\section{Availability of data and materials}

The sequences from this study have been deposited in GenBank under accession numbers KU754026-KU754035.

\section{Authors' contributions}

$J L W$ and $H C L$ conceived and designed the experiments; JLW, YWH, YZ and JXM performed the experiments; JLW collected the samples in the field, JLW analyzed the data; JLW wrote the paper; and DFL and AGX contributed reagents/materials. All authors read and approved the final manuscript.

\section{Authors' information}

This work was performed at the Yunnan Tropical and Subtropical Animal Viral Disease Laboratory, Yunnan Animal Science and Veterinary Institute, Kunming, Yunnan province. Qinglongshan, Jindian, Pang Long District, Kunming 650224, P.R. China.

\section{Competing interests}

The authors declare that they have no competing interests. The founding sponsors had no role in the study design, data collection and analysis, decision to publish, preparation of the manuscript, or the decision to publish the results.

\section{Consent for publication}

Not applicable.

\section{Ethics approval and consent to participate}

The study protocol was approved by the Institutional Review Board of the Yunnan Animal Science and Veterinary Institute, Kunming, China (protocol approval number: 201303035). The institutions approved the oral consent method prior to the initiation of the project, entitled: "A New Serotype of Tibet orbivirus Isolated from Culicoides Midges and Associated Infections in Animals in Yunnan, China", considering that individuals in the target population live in rural areas and receive little education. The purpose of the survey was explained to the district administrative authorities, and then to village leaders and local clinical doctors or veterinarians, before sample collection. Agreement was obtained from these community figures. Before mosquito and sera samples were collected from the domestic animals, the investigators explained the objectives of the sample collections to the head of the household, and informed oral consent was obtained from the head of the household with the assistance of village leaders and the rural doctors or veterinarians. No clinical investigation was conducted, and no personal identifiers were included; therefore, written informed consent was not sought for this study.

\section{Publisher's Note}

Springer Nature remains neutral with regard to jurisdictional claims in published maps and institutional affiliations.

Received: 4 November 2016 Accepted: 1 June 2017

Published online: 08 June 2017

References

1. Attoui $H$, Mertense PPC, Becnel J, Belaganahalli S. Virus taxonomy. In: King AMQ Adams MJ, Carstens EB, Lefkowitz EJ, editors. Ninth report of the International Committee on Taxonomy of Viruses. London: Elsevier; 2011. p. 1338.

2. Liu S, Huang G, Zhao Z, Hua Q. Animal arbovirus diseases and its inspection and quarantine technology. Beijing: Science Press; 2011. p. 5-29.

3. Purse BV, Brown HE, Harrup L, Mertens PP, Rogers DJ. Invasion of bluetonque and other orbivirus infections into Europe: the role of biological and climatic processes. Rev Sci Tech. 2008;27:427-42. PMID: 18819670.

4. Maclachlan NJ, Mayo CE. Potential strategies for control of bluetongue, a globally emerging, Culicoides-transmitted viral disease of ruminant livestock and wildlife. Antiviral Res. 2013;99:79-90. doi:10.1016/j.antiviral.2013.04.021. PMID: 23664958

5. Maclachlan NJ, Guthrie AJ. Re-emergence of bluetongue, African horse sickness, and other Orbivirus diseases. Vet Res. 2010;41:35. doi:10.1051/ vetres/2010007. PMID: 20167199.

6. Carpenter S, Wilson A, Mellor PS. Culicoides and the emergence of bluetongue virus in northern Europe. Trends Microbiol. 2009;17:172-8. doi:10.1016/j.tim.2009.01.001. PMID: 19299131.

7. Li M, Zheng Y, Zhao G, Fu S, Wang D, Wang Z, Liang G. Tibet orbivirus, a novel Orbivirus species isolated from Anopheles maculatus mosquitoes in Tibet, China. PLoS One. 2014;9(2):e88738. doi:10.1371/journal.pone.0088738. PMID: 24533145 
8. Lei W, Guo X, Fu S, Feng Y, Nie K, Song J, Li Y, Ma X, Liang G, Zhou H. Isolation of Tibet orbivirus, TIBOV, from Culicoides collected in Yunnan, China. PLoS One. 2015;10(8):e0136257. doi:10.1371/journal.pone.0139646. PMID: 26406242.

9. Wang J, Li H, He Y, Zhou Y, Meng J, Zhu W, Chen H, Liao D, Man Y. Isolation and genetic characterization of Mangshi virus: a newly discovered seadornavirus of the Reoviridae family found in Yunnan Province, China. PLoS One. 2015;10(12): e0143601. doi:10.1371/journal.pone.0143601. PMID: 26630378.

10. Wang J, Zhang H, Sun X, Fu S, Wang H, Feng Y, Wang H, Tang Q, Liang GD. Mosquitoes, mosquito-borne arboviruses and their infections of Yunnan Province, the China/Burma/Laos border. Am J Trop Med Hyg. 2011;84(5): 738-46. doi:10.4269/ajtmh. PMID: 21540383.

11. Jones RW, Ross J, Hoshino Y. Identification of parental origin of cognate dsRNA genome segment(s) of rotavirus reassortants by constant denaturant gel electrophoresis. J Clin Virol. 2003;26(3):347-54. PMID: 12637084.

12. Potgieter AC, Page NA, Liebenberg J, Wright IM, Landt O, van Dijk AA. Improved strategies for sequence-independent amplification and sequencing of viral double stranded RNA genomes. J Gen Virol. 2009;90:1423-32. doi:10.1099/vir.0. 009381-0. PMID: 19264638

13. Maan S, Maan NS, Samuel AR, Rao S, Attoui H, Mertens PP. Analysis and phylogenetic comparisons of full-length VP2 genes of the 24 bluetongue virus serotypes. J Gen Virol. 2007;88:621-30. PMID: 17251581.

14. Li W, Wang J, Li M, Fu S, Wang HY, Wang ZY, Jiang SY, Wang XW, Guo P, Zhao SC, et al. Mosquitoes and mosquito-borne arboviruses in the QinghaiTibet Plateau—focused on the Qinghai area, China. Am J Trop Med Hyg. 2010;82(4):705-11. doi:10.4269/ajtmh.2010.09-0649. PMID: 20348523.

15. Anthony SJ, Maan N, Maan S, Sutton G, Attoui H, Mertens PP. Genetic and phylogenetic analysis of the core proteins VP1, VP3, VP4, VP6 and VP7 of epizootic hemorrhagic disease virus (EHDV). Virus Res. 2009;145:187-99. doi: 10.1016/j.virusres.2009.07.011. PMID: 19632280.

16. Tan BH, Nason E, Staeuber N, Jiang W, Monastryrskaya K, Roy P. RGD tripeptide of bluetongue virus VP7 protein is responsible for core attachment to Culicoides cells. J Virol. 2001;75:3937-47. PMID: 11264382.

17. Basak AK, Gouet P, Grimes J, Roy P, Stuart D. Crystal structure of the top domain of African horse sickness virus VP7: comparisons with bluetongue virus VP7. J Virol. 1996;70:3797-806. PMID: 8648715.

18. Attoui H, Stirling JM, Munderloh UG, Billoir F, Brookes SM, Burroughs JN, de Micco P, Mertens PP, de Lamballerie X. Complete sequence characterization of the genome of the St Croix River virus, a new orbivirus isolated from cells of Ixodes scapularis. J Gen Virol. 2001;82:795-804. PMID: 11257184.

19. Belaganahalli MN, Maan S, Maan NS, Nomikou K, Kirkland PD, Attoui H, Brownlie J, Mertens PP. Full genome sequencing and genetic characterization of Eubenangee viruses identify pata virus as a distinct species within the genus orbivirus. PLoS One. 2012;7(3):e31911. doi:10.1371/journal.pone.0031911. PMID: 22438872

20. Mertens PPC, Maan S, Samuel A, Attoui H. Orbiviruses, reoviridae. In: Fauquet CM, Mayo MA, Maniloff J, Desselberger U, Ball LA, editors. Virus taxonomy eighth report of the International Committee on Taxonomy of Viruses. London: Elsevier/Academic Press; 2005. p. 466-83.

21. Attoui H, Mendez-Lopez MR, Rao S, Hurtado-Alendes A, Lizarazo-Caparo F, Jaafar FM, Samuel AR, Belhouchet M, Pritchard LI, Melville L, et al. Peruvian horse sickness virus and Yunnan orbivirus, isolated from vertebrates and mosquitoes in Peru and Australia. Virology. 2009;394:298-310. doi:10.1016/j. virol.2009.08.032. PMID: 19766284

22. Belaganahalli MN, Maan S, Maan NS, Tesh R, Attoui H, Mertens PP. Umatilla virus genome sequencing and phylogenetic analysis: identification of stretch lagoon orbivirus as a new member of the Umatilla virus species. PLoS One. 2011;6:e23605. doi:10.1371/journal.pone.0023605. PMID: 21897849.

23. Dilcher $M$, Weidmann $M$. Confusions in orbivirus protein classification. Virol J. 2012;9:166. doi:10.1186/1743-422X-9-166. PMID: 22909086.

24. Maan S, Maan NS, van Rijn PA, van Gennip RG, Sanders A, Wright IM, Batten C, Hoffmann B, Eschbaumer M, Oura CA, et al. Full genome characterization of bluetongue virus serotype 6 from the Netherlands 2008 and comparison to other field and vaccine strains. PLoS One. 2010;5:e10323. doi:10.1371/ journal.pone.0010323. PMID: 20428242.

25. Maan S, Rao S, Maan NS, Anthony SJ, Attoui H, Samuel AR, Mertens PP. Rapid CDNA synthesis and sequencing techniques for the genetic study of bluetongue and other dsRNA viruses. J Virol Methods. 2007;143(2): 132-9. PMID: 17433453
26. Anthony SJ, Maan S, Maan N, Kgosana L, Bachanek-Bankowska K, Batten C, Darpel KE, Sutton G, Attoui H, Mertens PP. Genetic and phylogenetic analysis of the outer-coat proteins VP2 and VP5 of epizootic hemorrhagic disease virus (EHDV): comparison of genetic and serological data to characterize the EHDV serogroup. Virus Res. 2009;145:200-10. doi:10.1016/j. virusres.2009.07.012. PMID: 19632281.

27. Huismans $H$, van Staden V, Fick WC, van Niekerk M, Meiring TL. A comparison of different orbivirus proteins that could affect virulence and pathogenesis. Vet Ital. 2004;40(4):417-25. PMID: 20422564.

28. Maan S, Maan NS, Nomikou K, Veronesi E, Bachanek-Bankowska K, Belaganahalli MN, Attoui H, Mertens PP. Complete genome characterization of a novel 26th bluetongue virus serotype from Kuwait. PLoS One. 2011;6:e26147. doi:10.1371/ journal.pone.0026147. PMID: 22031822.

29. Huang $X$. Isolation and identification of 17 strains virus from Tibet, China. J Arch Epidemiol Investigation. China: Military Medical Science Press; 1995. p. 122-7.

30. Chen J, Pan L. Detection for antibodies against orbivirus and its significance in Fujian Province. Chin J Zoonoses. 2000;16(2):16-8.

\section{Submit your next manuscript to BioMed Central and we will help you at every step:}

- We accept pre-submission inquiries

- Our selector tool helps you to find the most relevant journal

- We provide round the clock customer support

- Convenient online submission

- Thorough peer review

- Inclusion in PubMed and all major indexing services

- Maximum visibility for your research

Submit your manuscript at www.biomedcentral.com/submit
C Biomed Central 